\title{
Determination of true digestible amino acids of feedstuffs utilizing cecectomized roosters ${ }^{1}$
}

\author{
Eliane Aparecida da Silva², Luiz Fernando Teixeira Albino ${ }^{3}$, Horacio Santiago Rostagno ${ }^{3}$, \\ Rodolfo Alves Vieira², Valdir Ribeiro Junior², Anastácia Maria de Araújo Campos², João Paulo \\ Leles Pereira ${ }^{4}$
}

\footnotetext{
${ }^{1}$ Research financed by CAPES.

${ }^{2}$ Programa de Pós-Graduação em Zootecnia - DZO/UFV.

${ }^{3}$ DZO/UFV.

${ }^{4}$ Programa de Graduação em Zootecnia - DZO/UFV.
}

\begin{abstract}
The objective of this study was to estimate the true digestibility coefficients of amino acids and digestible amino acid values of some poultry feedstuffs. The feedstuffs were: babassu meal, sunflower meal, corn gluten meal, babassu starchy meal, meat and bone meal, common beans, pearl millet and residues of cookies, pasta and bread. The precise feeding method of Sibbald was used with adult cecectomized Leghorn roosters distributed in a completely randomized design, consisting of ten treatments and six replications with a rooster in each. The treatments were represented by the feedstuffs evaluated. The roosters were kept in a period of fasting for 36 hours and then fed 30 grams of feed. Samples were collected during 56 hours. Simultaneously, six roosters were kept fasting to make corrections to the metabolic and endogenous losses of amino acids. At the end of collections, the excreta obtained were weighed, freeze-dried and subsequently processed, so laboratory analyses were carried out and the coefficients of true digestibility of amino acids were determined. The mean values of the coefficients of true digestibility of essential and non-essential amino acids in percentage were respectively: 0.702 and 0.652 for the babassu meal; 0.852 and 0.786 for the sunflower meal; 0.928 and 0.887 for the corn gluten meal; 0.797 and 0.720 for the meat and bone meal; 0.364 and 0.339 for ground raw beans; 0.924 and 0.837 for ground pearl millet; 0.839 and 0.810 for cookie residue; 0.929 and 0.914 for pasta residue; and 0.904 and 0.899 for bread residue.
\end{abstract}

Key Words: amino acids, digestibility, poultry

\section{Introduction}

Some years ago, rations were formulated aiming to maximize animal performance without worries as to the excess nutrients. The requirements were estimated in the crude protein values of the ration. This often resulted in rations with a higher content of amino acids or with imbalance in relation to the actual requirements of animals. Thus, the reformulation of diets was demanded, so as to optimize the utilization of protein by the animal, relating not only the economic, but also the environmental factors and the sanitation conditions.

The use of the protein fraction of the ration has a direct effect on feed conversion, carcass quality and weight gain of animals. The development of animal nutrition, through better knowledge of the protein metabolism, better nutritional evaluation of the ingredients and production of industrial amino acids, enabled the optimization of rations, and consequently the possibility to meet the nutritional requirements in protein and amino acids for a lower cost and with negative impact of environmental pollution.
Several researchers utilize the digestibility values of amino acids to formulate rations of high quality for the production of meat and eggs, thus meeting the amino acid mixture more than the crude protein content of the diet (Coon, 1991). Digestibility must be understood as the measure of the disappearance of a nutrient during its passage through the digestive tract and not as its absorption, once the nutrient can be destroyed or modified by the action of the microorganisms in some parts of the digestive tract or metabolized by its walls during absorption (Rérat, 1990).

The apparent digestibility is obtained from the subtraction of the values of amino acids from the excreta or from material collected at the terminal ileum from the values of amino acids consumed; the true digestibility, in turn, is obtained with the values of endogenous amino acids from the excreta of animals fed a protein-free diet or from fasting animals. The digestibility of amino acids can be determined from certain methodologies such as, for example, the method of total collection of excreta with or without the utilization of marker; the method of ileum collection and the method of precise feeding of Sibbald with cecectomized roosters. 
The utilization of cecectomized roosters has been proposed, once the cecum is the greatest location of microbial activity of the gastrointestinal tract; and these microbes are capable of synthesizing amino acids or utilize them with no benefits to the birds (Neme et al., 2001).

The amino acids are not promptly available to absorption, so it is necessary to determine their digestibility coefficient in the different feedstuffs, which enables better use of these nutrients, in addition to increasing productivity and economic return (Fischer Júnior, 1997).

Therefore, the determination of the digestibility coefficients and of the content of digestible amino acids in the feeds is of extreme relevance, once the knowledge of the digestibility of nutrients represents improvement in the utilization efficiency of the feeds and increase in accuracy at the formulation of diets (Rostagno et al., 1999), especially when there is replacement of the traditional feedstuffs by alternative ones, which might result in deficient diets as a consequence of the amino acid digestibility.

Thus, the objective of this research was to estimate the true digestibility coefficients of amino acids and the values of digestible amino acids of the following feedstuffs: babassu, sunflower and corn gluten meals; babassu and meat and bone starchy meals; common beans; pearl millet; and residues of cookies, pasta and bread.

\section{Material and Methods}

A biological trial was conducted in the Aviculture sector of the Department of Animal Science of Universidade Federal de Viçosa, Minas Gerais, in which the method of precise feeding described by Sibbald (1979) was utilized with Leghorn cecectomized adult roosters weighing, on average, $1.90 \mathrm{~kg}$. The cecectomization surgery was performed according to the technique described by Pupa et al. (1998), which consists of an abdominal laparoscopy with local anesthesia.

The feedstuffs evaluated were: babassu, sunflower and corn gluten meals; babassu and meat and bone starchy meals; ground raw common beans; ground pearl millet; and residues of cookies, pasta and bread.

The design was completely randomized, in which each treatment was composed of six replications with a rooster per experimental unit. Simultaneously, six roosters were kept under the same experimental conditions, at fasting, receiving only water, for the determination of the endogenous and metabolic losses of amino acids.

The mean maximum and minimum temperatures recorded inside the shed during the experimental period were respectively 28.18 and $17.9^{\circ} \mathrm{C}$.
Roosters were housed in individual metal cages and, during an adaptation period of five days, received their feeding at two sessions of one hour each; one in the morning and the other in the afternoon, aiming to dilate the crop. Subsequently, they were subjected to a period of fast for 36 hours, to empty the digestive tract. After fasting, they were fed $30 \mathrm{~g}$ of the test feed with the aid of a funnel-probe introduced in the oral cavity up to the crop, which were divided in two periods of supply: at $7 \mathrm{~h} 00$ and $17 \mathrm{~h} 00$, so as to avoid regurgitation.

The total collection of excreta was done in intervals of 12 hours, on plastic-coated trays conditioned on the floor of the cages of each rooster, for a period of 56 hours after the supply of the first portion of the feed. The material collected was quantified and stored in freezer at $-20{ }^{\circ} \mathrm{C}$. At the end of the collection period, samples were lyophilized and homogenized, enabling the determination of the dry matter and total nitrogen values, along with samples of feeds. These analyses were conducted in the Laboratório de Nutrição Animal of the Departamento de Zootecnia of Universidade Federal de Viçosa, according to methodologies described by Silva (2002) and the analyses of the amino acids of the feed and excreta were conducted in the Animal Nutrition Laboratory Ajinomoto.

Knowing the quantities of amino acids ingested and excreted, as well as the endogenous fraction obtained with fasting roosters, the true digestibility coefficients of each amino acid of the feeds were determined, utilizing the formula proposed by Rostagno \& Featherston (1977):

$$
T D C a a=\frac{a a_{i n g}-\left(a a_{\text {exc }}-a a_{\text {end }}\right)}{a a_{\text {ing }}}
$$

in which TDCaa $=$ true digestibility coefficient of the amino acids; $\mathrm{aa}_{\text {ing }}=$ quantity of amino acids ingested, in $\mathrm{g} ; \mathrm{aa}_{\mathrm{exc}}=$ quantity of amino acids excreted, in $\mathrm{g}$; and $\mathrm{aa}_{\text {end }}=$ quantity of endogenous amino acids, in $\mathrm{g}$.

The digestibility coefficients of both essential and nonessential amino acids of the babassu starchy meal were not determined, due to the difficulty to supply the exact amount $(30 \mathrm{~g})$ of the feedstuff in question to the roosters, because the babassu starchy meal utilized in this study had an extremely fine granulometry (powder), which hindered the complete ingestion by the animals, so the content of digestible amino acids could not be calculated.

\section{Results and Discussion}

For the sunflower meal evaluated in this study, the content of total essential and non-essential amino acids was superior (Tables 1 and 2), except for amino acid 
tyrosine, which was inferior, in relation to the values found by Tavernari (2008). According to Freitas et al. (2004), in addition to other factors such as soil, climate and cultivar, in the case of sunflower meal, another important factor to be considered for the composition of the feed is the processing, in which the method of oil extraction and the quantity of hulls in the meal must be remarked. One can also observe that the content of lysine found for sunflower meal in this study was higher than the value mentioned by Embrapa (1991) $-9.0 \mathrm{~g} / \mathrm{kg}$, but lower than the values presented by Stringhini et al. (2000) $-9.5 \mathrm{~g} / \mathrm{kg}$ and by Sauvant et al. $(2004)-10.0 \mathrm{~g} / \mathrm{kg}$.

The values of both essential and non-essential total amino acids of the bread residues obtained in this study were superior to the values mentioned by Valadares Filho et al. (2006), once the crude protein content determined in this study was superior, and, as we all know, amino acids are the molecules which compose the proteins, so the higher the protein content in the feed, the higher the amino acid content.

The values of essential and non-essential total amino acids of the pasta residue were inferior to the values mentioned by Nunes et al. (2001), and also to the values determined by Rostagno et al. (2005), except for amino acids methionine, which was superior, and alanine, which was similar to the values found in this study.

The content of essential and non-essential total amino acids of the residue of cookies was inferior to those found both by Nunes et al. (2001) and Rostagno et al. (2005), which can be related to the protein content, since the crude protein values mentioned by these authors, 83.8 and $85.6 \mathrm{~g} / \mathrm{kg}$, respectively, were superior to the value found in this study.

These variations that occur in the composition of the ingredients are more evident in the byproducts, since for their obtainment there is not always standardization during the production process (Tucci et al., 2003).

The starchy meal of babassu presented low content both of essential and non-essential amino acids, once this ingredient presented low protein content: only $19.1 \mathrm{~g} / \mathrm{kg}$ crude protein in the natural matter and, according to Rodrigues et al. (2001), the direct relationship of the content of non-essential and essential amino acids with the crude protein content of the samples is evident.

Comparing the corn gluten meal evaluated in the present study with that evaluated by Brumano et al. (2006), one can observe that only amino acid arginine presented inferior value, whereas the other amino acids presented higher values, except for histidine, which had the same value in the two studies. The non-essential amino acid content of the corn gluten meal assessed was superior to that found by

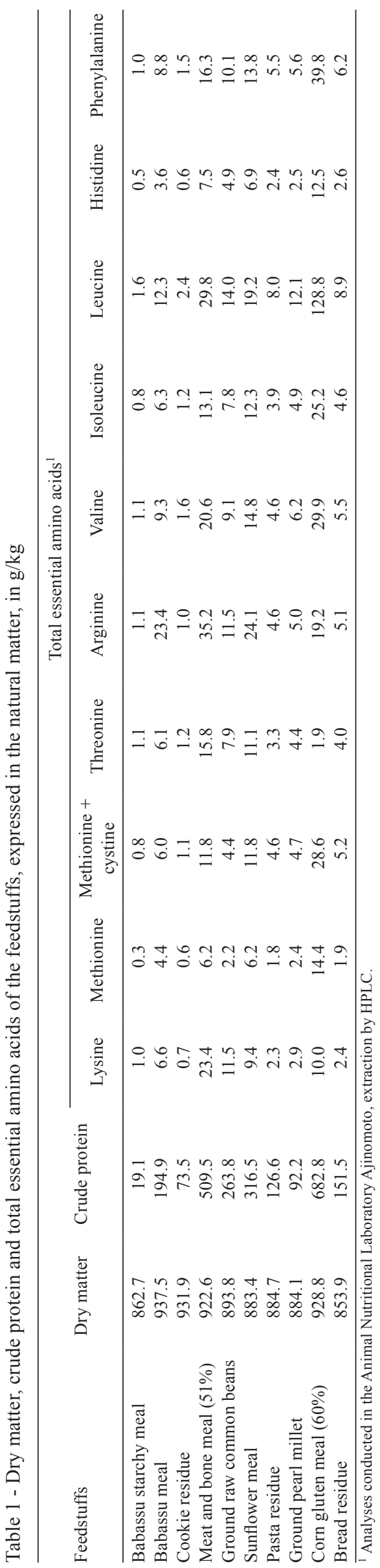

R. Bras. Zootec., v.41, n.9, p.2070-2078, 2012 
Table 2 - Dry matter, crude protein and total non-essential amino acids of the feedstuffs, expressed in the natural matter, in $\mathrm{g} / \mathrm{kg}$

\begin{tabular}{|c|c|c|c|c|c|c|c|c|c|}
\hline \multirow{2}{*}{ Feedstuffs } & \multirow{2}{*}{ Dry matter } & \multirow{2}{*}{ Crude protein } & \multicolumn{7}{|c|}{ Non-essential amino acids ${ }^{1}$} \\
\hline & & & Alanine & Aspartic acid & Glutamic acid & Cystine & Tyrosine & Serine & Glycine \\
\hline Babassu starchy meal & 862.7 & 19.1 & 1.2 & 2.0 & 2.0 & 0.5 & 0.7 & 1.3 & 1.3 \\
\hline Babassu meal & 937.5 & 194.9 & 8.3 & 16.4 & 37.5 & 1.6 & 4.4 & 8.6 & 8.9 \\
\hline Meat and bone meal (51\%) & 922.6 & 509.5 & 8.4 & 34.4 & 56.0 & 5.6 & 10.4 & 19.8 & 75.7 \\
\hline Ground raw common beans & 893.8 & 263.8 & 7.5 & 20.3 & 26.9 & 2.2 & 5.9 & 10.4 & 7.2 \\
\hline Sunflower meal & 883.4 & 316.5 & 12.9 & 26.8 & 59.0 & 5.6 & 7.3 & 13.1 & 17.0 \\
\hline Corn gluten meal $(60 \%)$ & 928.8 & 682.8 & 67.2 & 39.8 & 155.7 & 14.2 & 31.9 & 36.8 & 16.8 \\
\hline Bread residue & 853.9 & 151.5 & 4.4 & 5.9 & 41.5 & 3.4 & 3.4 & 6.3 & 5.1 \\
\hline
\end{tabular}

${ }^{1}$ Analyses conducted in the Animal Nutritional Laboratory Ajinomoto, extraction by HPLC.

Rodrigues et al. (2001a), except for amino acid isoleucine, which was inferior. The content of non-essential amino acids was also superior in relation to that found by Rodrigues et al. (2001a), except for amino acid glycine, which was equal to the value found in this study. The composition of the corn gluten meal can vary in function of the processing it undergoes and also the methods of obtainment.

The values of both essential and non-essential amino acids of meat and bone meal were inferior to the values found by Vieites et al. (2000), except for amino acid methionine, which was superior; the content of essential amino acid was also inferior to that obtained by Nery (2005), except for methionine + cystine, which was superior, which can be related to the protein content, once the crude protein value obtained in this study was inferior to the values obtained by Vieites et al. (2000) and Nery (2005), equal to $524.3 \mathrm{~g} / \mathrm{kg}$ and $536.6 \mathrm{~g} / \mathrm{kg}$ crude protein, respectively. According to Nunes et al. (2005), the crude protein content of the meat and bone meal is inversely proportional to the percentage of mineral matter, which is directly related to the proportion of bones or cartilaginous tissue contained in the meal. Besides, elevated variation in the chemical composition of the meat and bone meals can be verified, probably due to the differences in the proportions of the parts discarded in the slaughter and the processing methods. These differences in the chemical composition of animalorigin feedstuffs are expected, and reinforce the importance of the update of these values so that they can be utilized for the formulation of more precise diets that meet the animal requirements appropriately.

The total amino acid values obtained for pearl millet were inferior to those described by Rostagno et al. (2005), probably for presenting lower crude protein value in relation to that mentioned by these authors $-131.0 \mathrm{~g} / \mathrm{kg}$ crude protein. However, when compared with the values obtained by Bastos et al. (2004), similar values are observed for total amino acids. Comparing with the values of total amino acids mentioned by Valadares Filho et al. (2006), it can be observed that they were different from the values found in the present study. These differences observed in the total amino acid values can be due to variations between cultivars, climate, soil fertility, in addition to the processing which feedstuffs go through (Albino et al., 1987).

There was variation in the digestibility coefficients of the amino acids (Tables 3 and 4) of the feedstuffs assessed, when compared with the literature. According to Fischer Júnior (1997), these variations occur because of the chemical composition and also by variations in the values of endogenous excretion of the amino acids, which does not standardize endogenous losses. Besides, it can be observed that the mean values of the digestibility coefficients of the essential amino acids were superior to those of the nonessential; according to Ost et al. (2007), when the mean digestibility values of the essential and non-essential amino acids are contrasted, there is superiority of the essential amino acids over the non-essential, which may indicate a mechanism of the organism of birds for the better use of the nutritionally indispensable amino acids.

Among the ten feedstuffs evaluated, the common bean was the one which presented the lowest digestibility coefficient values for the 17 amino acids studied, which can be explained by the presence of anti-nutritional factors contained in the raw beans and, according to Bonett et al. (2007), there are several substances contained in beans which act as anti-nutritional factors, among which tannins, phytates, protease inhibitors and lectins stand out. These substances might act inhibiting the action of digestive enzymes, complexing with the nutrients (carbohydrates, amino acids and minerals), hindering their absorption and utilization by birds. These anti-nutritional factors, at most times, are inhibited by thermal processes, once they are considered thermolabile; and the beans utilized in this 


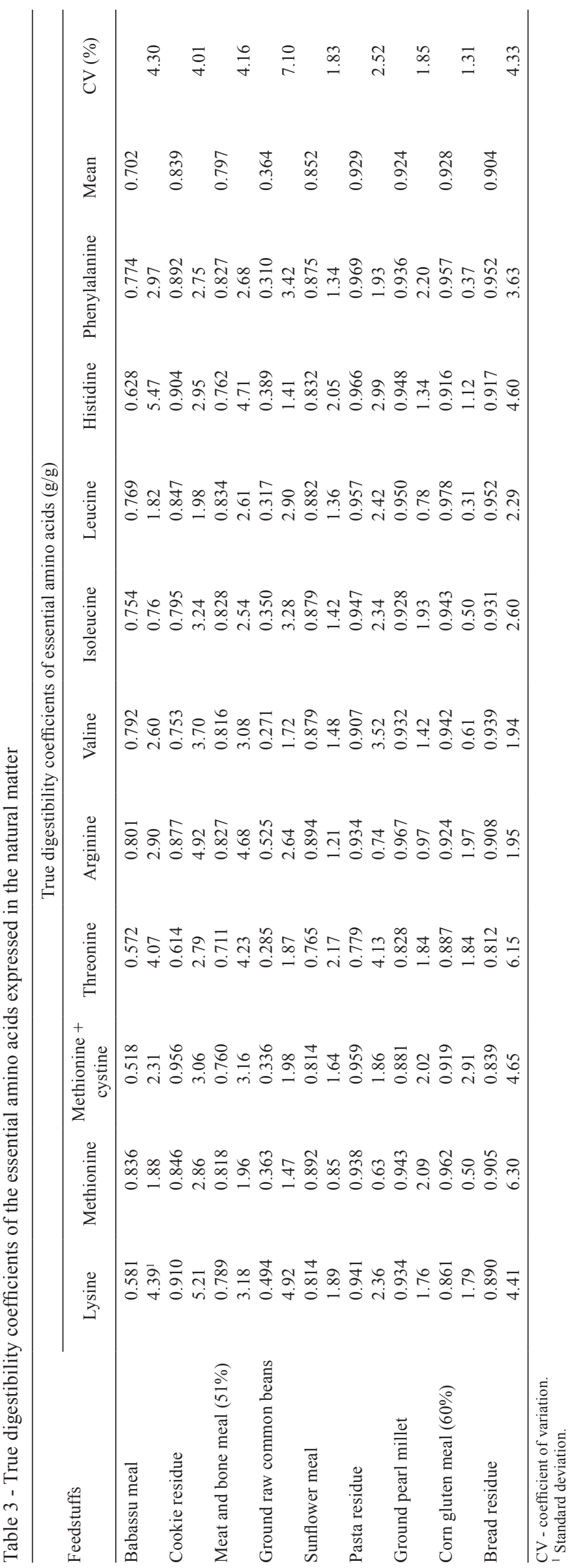

experiment did not undergo any type of thermal process. Huisman (1991) comments that the anti-nutritional factors, which interfere in digestion, absorption and utilization of nutrients, give the plants a natural protection against the attack of bacteria, insects and birds, which causes disturbances in their digestive processes. According to Pupa (1995), anti-nutritional factors like inhibitors of trypsin and chymotrypsin, of lectins, of phenolic compounds and of saponins, present in many seeds, cause the depressant effect on the digestion and utilization of protein and, moreover, King et al. (2000) reported that the anti-nutritional effect of the tannin of feedstuffs is, in part, due to its inhibiting action on the transport of proteins and amino acids in brush border.

For the sunflower meal evaluated, the true digestibility coefficients of the essential amino acids were inferior to the values determined by Tavernari (2008), except for amino acids lysine, methionine and valine, which were superior. As for the non-essential amino acids, it can be observed that the true digestibility coefficient values were superior to amino acids alanine and glutamic acid, whereas the others, cystine, aspartic acid, serine and tyrosine, were inferior to the values found by this author. These variations for the digestibility coefficient are a result of the different experimental procedures, such as the amount of feed ingested and the purity of the material collected, which is associated with the number of collections per day, and possible differences in the laboratory analyses.

The true digestibility coefficients of both essential and non-essential amino acids of the babassu meal were low, given that this feedstuff is a residue from the extraction of the babassu coconut oil, constituted mainly of the most fibrous parts of the fruit, the mesocarp, epicarp and endocarp (layer that cover the nuts) and also by the nuts, i.e., it is an extremely fibrous feedstuff. The low speed of the fiber degradation by birds, coupled with the long time of passage of the feed through their gastrointestinal tract, contribute to the obtainment of the low values of digestibility coefficient of amino acids in feedstuffs with a high content of fiber (Nery, 2005). Coon et al. (1990) observed, in roosters, that the digestibility of amino acids in the soybean meal was $0.916 \mathrm{~g} / \mathrm{g}$ when alpha-galactosides were extracted with ethanol and 0.880 in the regular soybean meal, with the digestibility of methionine, alanine, valine and lysine improved by the use of extraction of oligosaccharides with ethanol, showing that the fiber can affect the digestibility of the amino acids.

The pasta residue presented true digestibility coefficients of essential amino acids superior to the values determined by Nunes et al. (2001), except for amino acids threonine and 
Table 4 - True digestibility coefficients of the non-essential amino acids expressed in the natural matter

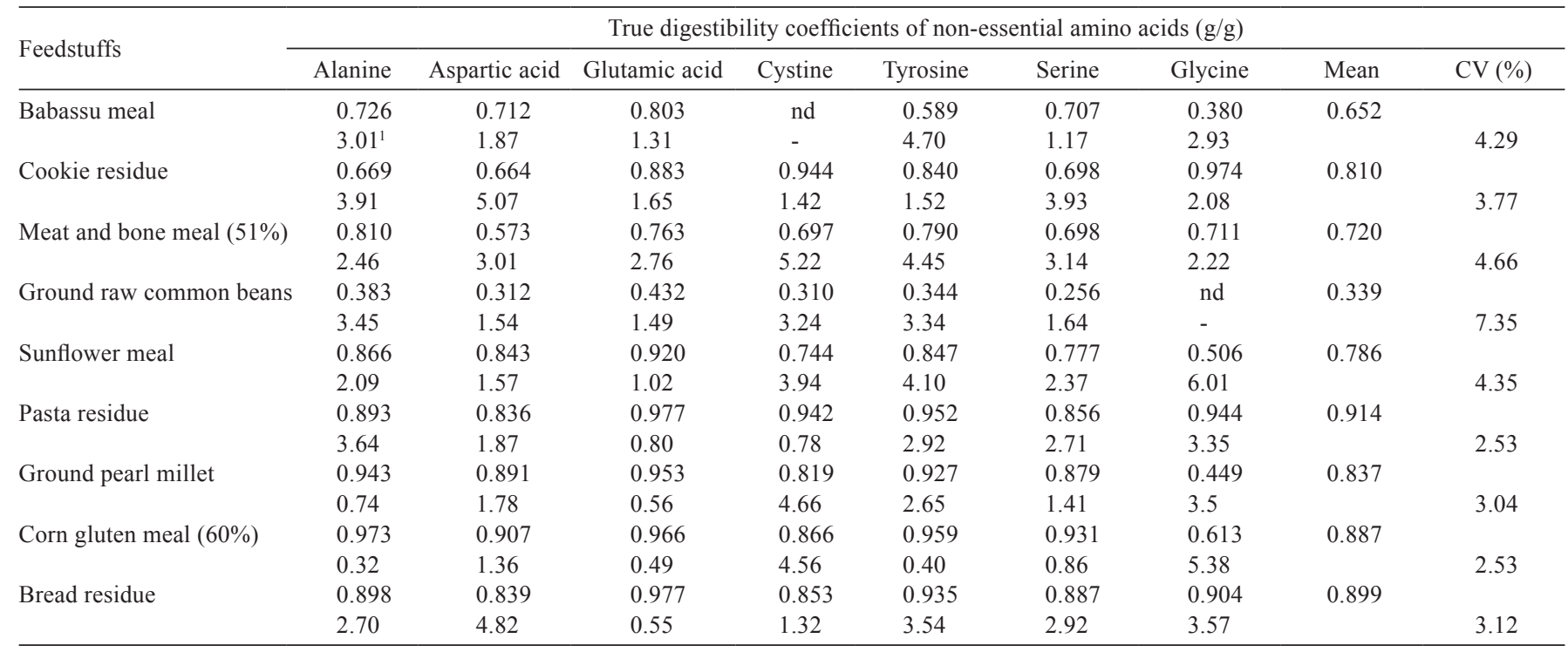

$\mathrm{CV}$ - coefficient of variation; nd - not determined.

${ }^{1}$ Standard deviation.

arginine, which were superior. As for the true digestibility coefficients of the non-essential amino acids, one can observe that the values determined were inferior to those obtained by these authors, except for amino acids, glutamic acid and serine, which were superior. These variations observed in the digestibility of amino acids can be related to the animals utilized in the experiments, once, when cecectomized roosters are utilized, there can be alteration in the regulation of the passage rate of the feed or in the absorption of nutrients by the intestine; furthermore, the age and size of animals also interfere directly in the nutrient digestibility. The roosters utilized in the present study were lighter, with average weight of approximately $1900 \mathrm{~g}$ in relation to those utilized by Nunes et al. (2001), which weighed, on average, $2365 \mathrm{~g}$.

The true digestibility coefficients of the essential amino acids of the residue from cookies were different from the values mentioned by Rostagno et al. (2005); besides, the true digestibility coefficients of the non-essential amino acids were inferior to those determined by Nunes et al. (2001), except for amino acids cystine and tyrosine, which were superior. In addition to the animals utilized in the experiments, another factor that might contribute to the occurrence of these differences in the digestibility coefficients is the ambient temperature: the minimum and maximum temperatures recorded in the present study were 28.18 and $17.9^{\circ} \mathrm{C}$, respectively, whereas the maximum and minimum temperatures recorded by Nunes et al. (2001) were 23.8 and $17.1^{\circ} \mathrm{C}$, respectively.

Among the several factors that interfere in the digestibility of amino acids, in addition to the ones linked to the physiology of the animal, to the methodology employed for the determination of the digestibility and to the ambient temperature during the experimental period, there are also, for instance, the method of processing and storing of the feedstuffs, the composition of feedstuffs itself and the presence of anti-nutritional factors in the feedstuffs, like tannins, protease inhibitors, non-amylaceous soluble polysaccharides and phytate.

Observing the true digestibility coefficients of the essential amino acids of corn gluten meal, one can notice that the values determined in this study were superior to those determined by Brumano et al. (2006), except for leucine, which was inferior, and valine, which was similar. The true digestibility coefficients of the non-essential amino acids, in turn, were inferior, except for alanine, which was higher than the values found by that author. The true digestibility coefficients of the essential amino acids were also inferior to the values found by Rodrigues et al. (2001a).

Except for leucine, the true digestibility coefficients of the essential amino acids of the meat and bone meal determined in the present study were different from the values determined by Nery (2005), as well as the values mentioned by Rostagno et al. (2005), whereas the true digestibility coefficients of the non-essential amino acids were inferior to the values found by Vieites et al. (1999). The differences in the composition of the feedstuffs can also interfere in the digestibility coefficients of the nutrients, e.g., in the case of the meat and bone meal, in which there is no standardization during the processing to its obtainment, thus leading to variations mainly in the content of mineral matter and protein; Johnson et al. (1998) affirmed that 
elevated contents of ash cause decrease in the amount of protein, decreasing the levels of essential amino acids per unit of protein, without affecting its quality.

The pearl millet presented different true digestibility coefficients of essential amino acids from the two varieties assessed by Rodrigues et al. (2001a), like Rostagno et al. (2005), who showed different values, except for arginine, which presented value similar to that of the present study. These differences can be related to the fiber content of the feedstuff, once the neutral detergent fiber (NDF) and acid detergent fiber (ADF) contents were different between the feedstuffs; for the pearl millet evaluated in the present study, the NDF was $267.2 \mathrm{~g} / \mathrm{kg}$, and ADF was $38.1 \mathrm{~g} / \mathrm{kg}$; for the two varieties evaluated by Rodrigues et al. (2001b), they were equal to $175.8 \mathrm{~g} / \mathrm{kg}$ and $210.8 \mathrm{~g} / \mathrm{kg}$ NDF; $76.5 \mathrm{~g} / \mathrm{kg}$ and $100.3 \mathrm{~g} / \mathrm{kg}$ ADF; and by Rostagno et al. (2005), $193.3 \mathrm{~g} / \mathrm{kg}$ NDF and $96.6 \mathrm{~g} / \mathrm{kg}$ ADF. According to Johson (1992), the fiber content can influence the digestibility values due to alterations in the endogenous excretion of the animals.

There were differences between the content of digestible amino acids (Tables 5 and 6 ) in relation to the literature consulted, due to differences in the composition of feedstuffs and also to the different digestibility coefficients for each amino acid studied.

The formulation of diets based on digestible amino acids has been utilized by nutritionists especially because of the need to optimize the use of raw materials of high cost and also for enabling the replacement of corn and soybean by alternative ingredients, ensuring an equivalent uptake of digestible amino acids by the correction of the deficiencies with supplementation of industrial amino acids (Sakomura \& Rostagno, 2007). In addition, according to Rostagno et al. (1995), the use of non-conventional feedstuffs, when supplemented adequately with industrial amino acids, promotes decrease in the cost per kilogram of meat produced.

According to Degussa (1993) the value of a protein depends on its content of essential amino acids and its availability to the metabolism of birds. When considering amino acids as to their digestibility, it is possible to supply them adequately. For Parsons et al. (1995), the formulation of diets based on digestible amino acids with alternative ingredients yields better performance than those formulated based on total amino acids. And not knowing the actual amount of digestible amino acids in the different feedstuffs utilized in the formulation may bring about under or overconsumption of amino acids, thus affecting production (Nunes et al., 2001).

The digestible essential and non-essential amino acid values of sunflower meal were different from the values

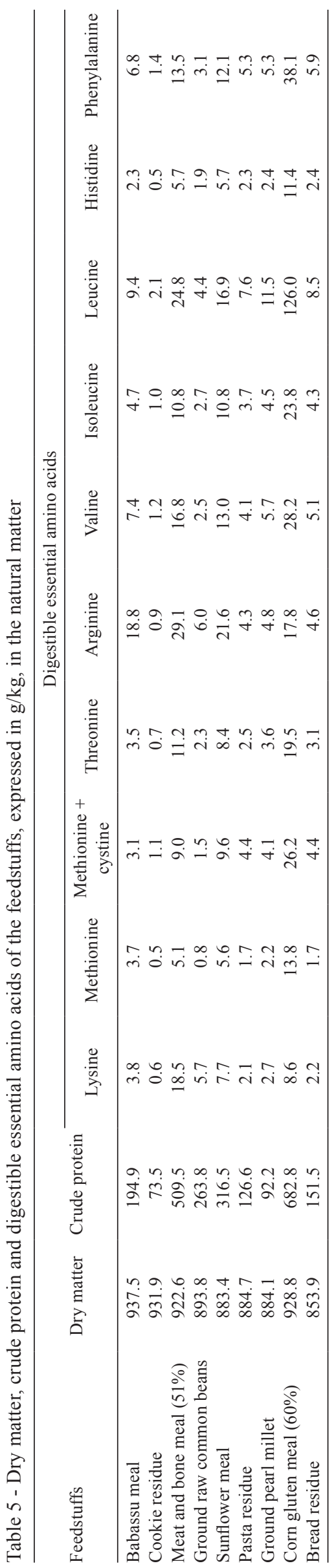

R. Bras. Zootec., v.41, n.9, p.2070-2078, 2012 
Table 6 - Dry matter, crude protein and digestible non-essential amino acids of the feedstuffs, expressed in $\mathrm{g} / \mathrm{kg}$, in the natural matter

\begin{tabular}{|c|c|c|c|c|c|c|c|c|c|}
\hline \multirow{2}{*}{ Feedstuffs } & \multirow{2}{*}{ Dry matter } & \multirow{2}{*}{ Crude protein } & \multicolumn{7}{|c|}{ Digestible non-essential amino acids } \\
\hline & & & Alanine & Aspartic acid & Glutamic acid & Cystine & Tyrosine & Serine & Glycine \\
\hline Babassu meal & 937.5 & 194.9 & 3.8 & 11.7 & 30.1 & nd & 2.6 & 6.1 & 3.4 \\
\hline Cookie residue & 931.9 & 73.5 & 0.8 & 1.3 & 6.0 & 0.5 & 0.7 & 1.2 & 0.9 \\
\hline Ground raw common beans & 893.8 & 263.8 & 2.9 & 6.3 & 11.6 & 0.7 & 2.0 & 2.7 & nd \\
\hline Sunflower meal & 883.4 & 316.5 & 11.2 & 22.6 & 54.3 & 4.1 & 6.2 & 10.2 & 8.6 \\
\hline Pasta residue & 884.7 & 126.6 & 3.3 & 4.1 & 36.2 & 2.6 & 2.9 & 4.7 & 3.9 \\
\hline Bread residue & 853.9 & 151.5 & 3.9 & 5.0 & 40.6 & 2.9 & 3.2 & 5.6 & 4.6 \\
\hline
\end{tabular}

nd - not determined.

described by Sauvant et al. (2004). Overall, these values were superior to those determined by Tavernari (2008).

The values of both digestible essential and non-essential amino acids of the cookie residue evaluated were inferior to the values determined by Nunes et al. (2001), and to those mentioned by Rostagno et al. (2005).

The pasta residue presented digestible essential amino acid values superior to the values mentioned by Rostagno et al. (2000); for amino acids methionine + cystine and isoleucine, the values were inferior. The digestible amino acid values for aspartic acid, glutamic acid and serine, in turn, were superior; the values for digestible amino acids alanine and tyrosine were inferior, in relation to the values determined by Nunes et al. (2001).

The corn gluten meal presented digestible amino acid values different from those mentioned by Sauvant et al. (2004), except for isoleucine, which was similar to the value mentioned by these authors. The digestible essential amino acid values were superior those found by Brumano (2005), except for amino acids lysine, arginine and histidine, which were inferior. The digestible non-essential amino acid values determined in this study were superior to those found by the last-mentioned author, except for glycine, which was inferior.

Except for cystine, all the digestible amino acid values of the meat and bone meal were inferior to the values mentioned by Sauvant et al. (2004). The values of digestible essential amino acids were inferior, except for phenylalanine, which was superior to the value mentioned by Rostagno et al. (2000). Vieites et al. (1999) reported that, when utilized in diets for birds, the meat and bone meal must be formulated based on its composition of digestible amino acids for the limiting amino acids to be properly supplemented.

Pearl millet presented digestible essential amino acid values different from those mentioned by Rostagno et al. (2000), except for amino acids methionine + cystine and isoleucine, which were similar to the values determined in this study.
Furthermore, it presented digestible essential amino acid values inferior to the ones mentioned by Rostagno et al. (2005).

These differences found between the feedstuffs demonstrate the importance of always updating the data, not only of composition, but also of the digestibility of the nutrients contained in the feedstuffs for the most exact diets to be produced, so as to meet the nutritional requirement of animals, thus avoiding waste or lack of nutrients.

\section{Conclusions}

The mean values of the true digestibility coefficients of essential and non-essential amino acids expressed in the natural matter, in $\mathrm{g} / \mathrm{g}$ are, respectively: 0.702 and 0.652 for the babassu meal; 0.852 and 0.786 for the sunflower meal; 0.928 and 0.887 for the corn gluten meal; 0.797 and 0.720 for the meat and bone meal; 0.364 and 0.339 for ground raw beans; 0.924 and 0.837 for ground pearl millet; 0.839 and 0.810 for cookie residue; 0.929 and 0.914 for pasta residue; and 0.904 and 0.899 for bread residue.

\section{References}

ALBINO, L.F.T.; COELHO, M.G.R.; RUTZ, F. et al. Valores energéticos e de triptofano de alguns alimentos determinados, em aves jovens e adultas. Pesquisa Agropecuária Brasileira, v.22, p.1301-1306, 1987.

BASTOS, A.O.; MOERIRA, I.; MURAKAMI, A.E.M. et al. Utilização do milheto (Penisetum glaucum (L.) Brown) grão na alimentação de suínos na fase inicial (15-30 kg de peso vivo). Revista Ciência Rural, v.34, n.6, p.1915-1919, 2004.

BONETT, L.P.; BAUMGARTHER, M.S.T.; KLEIN, A.C. et al. Compostos nutricionais e fatores antinutricionais do feijão comum (Phaseolus vulgares L.). Arquivos de Ciência da Saúde, v.11, n.3, p.235-246 2007.

BRUMANO, G. Composição química e valores de energia metabolizável e de aminoácidos digestíveis de alimentos protéicos para aves. 2005. 83f. Dissertação (Mestrado em Zootecnia) - Universidade Federal de Viçosa, Viçosa, MG.

BRUMANO, G.; GOMES, P.C.; ALBINO, L.F.T. et al. Composição química e valores de energia metabolizável de alimentos protéicos para frangos de corte em diferentes idades. Revista Brasileira de Zootecnia, v.35, n.6, p.2297-2302, 2006.

COON, C.N.; LESKE, L.K.; AKAVANICHAN, O. et al. Effect of oligosaccharide-free soybean meal on true metabolizable energy 
and fiber digesttion in adult roosters. Poultry Science, v.69, n.5, p.787-793, 1990.

COON, C.N. Optimizing ingredient utilization through a better understanding of amino acid bioavailability. In: TECHNICAL SYMPOSIA, 1991, Aruba. Proceedings... Aruba: NOVUS INTERNATIONAL, 1991. p.11-40.

DEGUSSA, A.G. Digestible aminoacids in feedstuffs for poultry. Frankfurt: 1993, 18p.

EMPRESA BRASILEIRA DE PESQUISA E AGROPECUÁRIA EMBRAPA. Tabela de composição química e valores energéticos de alimentos para suínos e aves. 3.ed. Concórdia: Centro Nacional de Pesquisa de Suínos e Aves, 1991. 97p. (Documentos, 19).

FARIA, D.E.; SANTOS, A.L. Exigências nutricionais de galinhas poedeiras. In: SIMPÓSIO INTERNACIONAL SOBRE EXIGÊNCIAS NUTRICIONAIS DE AVES E SUÍNOS, 2., 2005, Viçosa, MG. Anais... Viçosa, MG: Universidade Federal de Viçosa, 2005. p.315-329.

FISCHER JÚNIOR, A.A. Valores de energia metabolizável e de aminoácidos digestíveis de alguns alimentos para aves. 1997. 55f. Dissertação (Mestrado em Zootecnia) - Universidade Federal de Viçosa, Viçosa, MG.

FREITAS, E.R.; SAKOMURA, N.V.; NEME, R. et al. Determinação da digestibilidade dos nutrientes e da energia metabolizável da semente e do farelo de girassol para frangos de corte. In: REUNIÃO ANUAL DA SOCIEDADE BRASILEIRA DE ZOOTECNIA, 41., 2004, Campo Grande. Anais... Campo Grande: Sociedade Brasileira de Zootecnia, 2004. p.1-4.

HUISMAN, J. Anti-nutritional factors in poultry feed and their management. In: EUROPEAN SYMPOSIUM POULTRY NUTRITION, 8., 1991, Venezian Meske, Italy. Proceedings... Venezian Meske, 1991. p.35-52.

JOHNSON, M.L.; PARSONS, C.M.; FAHEY, G.C. Effects of special raw material source, ash content and processing temperature on amino acid digestibility of animal by-product meals by cecectimized roosters and ileally cannulated dogs. Journal Animal Science, v.4, n.76, p.1112-1121, 1998.

JOHSON, R.J. Principles problems and application of amino acid digestibility in poultry. Worlds Poultry Science Journal, v.48, n.3, p.232-246, 1992.

KING, D.; FAN, M.Z.; EJETA, G. et al. The effects of taninnins on nutrient utilization in the white pekin duck. British Poultry Science, v.41, n.5, p.630-639, 2000.

NEME, R.; ALBINO, L.F.T.; ROSTAGNO, H.S. et al. Digestibilidade verdadeira da lisina $\mathrm{HCl}$ e da lisina sulfato determinada com galos cecectomizados. Revista Brasileira de Zootecnia, v.30, n.5, p.1531-1535, 2001.

NERY, L.R. Valores de energia metabolizável e aminoácidos digestíveis de alguns alimentos para aves. 2005. 87f. Dissertação (Mestrado em Zootecnia) - Universidade Federal de Viçosa, Viçosa, MG.

NUNES, R.V.; ROSTAGNO, H.S.; ALBINO, L.F.T. et al. Valores de aminoácidos digestíveis verdadeiros e equações de predição dos aminoácidos digestíveis do grão e de subprodutos do trigo para aves. Revista Brasileira de Zootecnia, v.30, n.3, p.774-784, 2001.

NUNES, R.V.; POZZA, P.C.; NUNES, C.G.V. et al. Valores energéticos de subprodutos de origem animal para aves. Revista Brasileira de Zootecnia, v.34, n.4, p.1217-224, 2005.

OST, P.R.; RODRIGUES, P.B.; FREITAS, R.T.F. et al. Aminoácidos digestíveis verdadeiros de alguns alimentos protéicos determinados com galos cecectomizados e por equações de predição. Revista Brasileira de Zootecnia, v.36, n.6, p.1820-1828, 2007.

PARSONS, C.M.; FERNANDES, S.R.; YE ZANG. Dietary formulation with cottonsed meal on a total amino acids versus digestible amino acids basis. Poultry Science, v.74, n.7, p.1168-1179, 1995.

PUPA, J.M.R. Rações para frangos de corte formuladas com valores de aminoáidos digestíveis verdadeiros, determinados com galos cecectomizados. 1995. 63f. Dissertação (Mestrado em Zootecnia) - Universidade Federal de Viçosa, Viçosa, MG.

PUPA, J.M.R.; LEÃO, M.I.; CARVALHO, L.G. et al. Cecectomia em galos sob anestesia local e incisão abdominal. Arquivo Brasileiro Medicina Veterinária e Zootecnia, v.50, n.5, p.531-535, 1998.

RÉRAT, A. Absorption of nitrogen and aminoacids from exogenous (fish meal proteins) or endogenous sources in the pig. Pigs New and Information, v.11, n.2, p.173-180, 1990.

RODRIGUES, P.B.; ROSTAGNO, H.S.; ALBINO, L.F.T. et al. Aminoácidos digestíveis verdadeiros do milheto, milho e subprodutos do milho determinados com galos adultos cecectomizados. Revista Brasileira de Zootecnia, v.30, n.6, p.2046- 2058, 2001a.

RODRIGUES, P.B.; ROSTAGNO, H.S.; ALBINO, L.F.T. et al. Valores energéticos do milheto, do milho e subprodutos do milho, determinados com frangos de corte e galos adultos. Revista Brasileira de Zootecnia, v.30, n.6, p.1767-778, 2001b.

ROSTAGNO, H.S.; ALBINO, L.F.T; DONZELE, J.L. et al. Tabelas brasileiras para aves e suínos: composição de alimentos e exigências nutricionais. Viçosa, MG: Universidade Federal de Viçosa, 2000. 141p.

ROSTAGNO, H.S.; ALBINO, L.F.T; DONZELE, J.L. et al. Tabelas brasileiras para aves e suínos: composição de alimentos e exigências nutricionais. Viçosa, MG: Universidade Federal de Viçosa, 2005. 186p.

ROSTAGNO, H.S.; FEATHERSTON, W.R. Estudo de métodos de determinação de disponibilidade de aminoácidos em pintos. Revista Brasileira de Zootecnia, v.6, p.64-75, 1977.

ROSTAGNO, H.S.; NASCIMENTO, A.H.; ALBINO, L.F.T Aminoácidos totais e digestíveis para aves. In: SIMPÓSIO INTERNACIONAL SOBRE NUTRIÇÃO DE AVES, 2000, Campinas. Anais... Campinas: FACTA, 1999. p.65-83.

ROSTAGNO, H.S.; PUPA, J.M.R.; PACK, M. Diet formulation for broilers based on total versus digestible amino acids. Journal Applied Poultry Science, n.4, p.293-299, 1995.

SAKOMURA, N.K.; ROSTAGNO, H.S. Métodos de pesquisa em nutrição de monogástricos. Jaboticabal: Funep, 2007. 283p.

SAUVANT, D.; PEREZ, J.M.; TRAN, G. Tablas de composición y de valor nutritivo de las materias primas destinadas a los animales de interés ganadero: cerdos, aves, bovinos, ovinos, caprinos, conejos, caballos, peces. Madrid: Ediciones Mundi Prensa, 2004. 195p.

SIBBALD, I.R. A bioassay for metabolizable energy in feeding stuffs. Poultry Science, v.55, n.1, p.303-308, 1976.

SILVA, D.J.; QUEIROZ, A.C. 2002. Análise de alimentos (Métodos químicos e biológicos). 3.ed. Viçosa, MG: UFV. 235p.

STRINGHINI, J.H.; CAFÉ, M.B.; FERNANDES, C.M. et al. Avaliação do valor nutritivo do farelo de girassol para aves. Revista Ciência Animal Brasileira, v.1, n.2, p.123-126, 2000.

TAVERNARI, F.C. Digestibilidade dos aminoácidos e valores energéticos do farelo de girassol e sua inclusão na ração de frangos de corte. Universidade Federal de Pernambuco, 2008. 78f. Dissertação (Mestrado em Zootecnia) - Universidade Federal Rural de Pernambuco, Recife.

TUCCI, F.M.; LAURENTIZ, A.C.; SANTOS, E.A. Determinação da composição química e dos valores energéticos de alguns alimentos para aves. Acta Scientarum Animal Sciences, v.25, n.1, p.85-89, 2003.

VALADARES FILHO, S.C. Tabelas brasileiras de composição de alimentos para bovinos. Viçosa, MG: Universidade Federal de Viçosa, 2006. 329p.

VIEITES, F.M.; ALBINO, L.F.T.; SOARES, P.R. et al. Valores de aminoácidos digestíveis verdadeiros de farinha de carne e ossos para aves. In: REUNIÃO ANUAL DA SOCIEDADE BRASILEIRA DE ZOOTECNIA, 36., 1999, Porto Alegre. Anais... Porto Alegre: Sociedade Brasileira de Zootecnia, 1999. (CD-ROM).

VIEITES, F.M.; ALBINO, L.F.T.; SOARES, P.R. et al. Valores de aminoácidos digestíveis da farinha de carne e ossos para aves. Revista Brasileira de Zootecnia, v.29, n.6, p.2300-2307, 2000. 